Gamification and Essential Determinates of Motivational Level...

Dr/ Niveen Ezzat Aly

\title{
Gamification and Essential Determinates of Motivational Level An Application of Self-Determination Theory in Egypt
}

\section{Niveen Ezzat Aly}

Assistant Professor

Cairo University, Faculty of Commerce, Business Administration

\section{Abstract}

Gamification has become a trend in organizations in different industries. However, little research has empirically analyzed its potential for recruitment. This research aims to determine the extent of significant differences in motivational level between job seekers who used gamification (Gamification Group) GG and those who did not (Non-Gamification) NG. Also, to identify the significant differences in motivational level from use of gamification according to their characteristics. The comparative inferential descriptive method was applied. To measure the motivational level researcher used the Intrinsic Motivation Inventory Scale. The research was an experimental study the two groups are the experimental who used gamification on the recruiter site, and the control group that did not use gamification but other methods like emails or in-person. The research population was all job seekers and students of the Faculty of Commerce, Cairo University (Georgia, and English Section) at

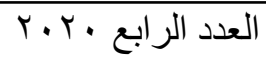

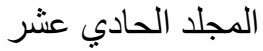


Gamification and Essential Determinates of Motivational Level...

Dr/ Niveen Ezzat Aly

the undergraduate and postgraduate levels (MBA) in the second semester of the academic year 2018-2019 who search for vacancies (job-seekers). Convenience Sampling was applied, the sample size was 400, divided into two equal groups one for the (GG) and the other for (NG) data gathered via an online survey. The results of the study confirmed the existence of significant differences in the level of motivation between the two groups, and the results proved that there were no significant differences in the motivational level of (GG) according to their characteristics. There is only one recruiter company applying gamification in recruitment processes in Egypt (Hire Hunt) this study depends on the use of its interactive platform. This research is genuine for being the first experimental study in Egypt regarding gamification and motivation for job-seekers perspectives. This study provides a theoretical foundation based on Self- Determination Theory (SDT) and empirical support for the use of business simulation games in gamified recruitment processes.

Key words: Gamification, SDT, Online Recruitment, IMI

\section{Introduction}

In recent decades, technical advancements have helped companie s develop new recruiting methods, some based on the Internet (e.g., computerized databases, online interviews, online personality tests), known as online recruitment and more recently

$$
\text { العدد الرابع • r. T }
$$$$
\text { المجلد الحادي عشر }
$$ 
Gamification and Essential Determinates of Motivational Level...

Dr/ Niveen Ezzat Aly

based on social networks (e.g., LinkedIn), known as social recruitment. Digital technologies are changing how people look for jobs and how companies recruit. Today, companies are changing the way they attract and hire qualified employees, by adopting a new and more enjoyable approach to online and social recruitment: gamified recruitment (Buil, I., Catalán, S. and Martínez, E., 2020). In the last few years, gamification has gained growing attention in a number of areas, including employment, education, advertisement, health care, soc ial networks and online communities. (Koivisto \& Hamari, 2019). Large organizations, such as L'Oréal, PwC, Google, the US Army, and the British Intelligence Service, employ gamified tools for recruitment (Buil, I., Catalán, S., \& Martínez, E. (2020). The ability to attract and recruit talented employees is a source of competitive advantage for any organization (Serrat, 2017).

Gamification is an interdisciplinary approach seeking to motivate users to achieve certain behavioral or psychological outcomes. It refers to a design strategy to develop infrastructure and processes that provide similar interactions to those produced by games (Deterding, Dixon, Khaled, \& Nacke, 2011; Hamari, Huotari, \& Tolvanen, 2015; Huotari \& Hamari, 2012; Liu et al., 2017; Santhanam et al., 2016; Vesa et al., 2017). The central idea is to harness the motivational power of games by applying game design elements (e.g., points, rules, challenges, badges, competition, voluntary play, and uncertain outcomes) into non-



المجلد الحادي عشر 
Gamification and Essential Determinates of Motivational Level...

Dr/ Niveen Ezzat Aly

game contexts (Deterding et al., 2011, Seaborn and Fels, 2015). Gamification facilitates the processes necessary to attract and reach the most qualified candidates due to the use of specialized software that analyzes the data collected (Mohamed Badr EIDin Aboul-Ela, 2014). It is a new type of online recruitment, defined as the use of game design elements, also called game mechanics, to engage end-users in non-game contexts (Huotari \& Hamari, 2017). The literature includes several optimistic predictions for the use of gamification and proposes its usefulness in different disciplines. The potential of gamification to promote motivation and engagement for a wide range of activities had also attracted managers in different fields. Gamification has recently been recognized as significant in the area of human resource management (Armstrong, Landers, \& Collmus, 2016). The elements of gamification differ according to the field of application and the purpose for which it is used.

In this research, gamification is considered as a gamified recruitment tool based on serious games that are primarily used to test candidates' ability to make decisions, improvise, analyze situations and propose solutions, among other attributes (AllalChérif, 2014); that is, for purposes of selection. Despite the high popularity and use of gamified recruitment, few researchers have studied the motivational level of job candidates. Hence, recent studies have called for more research into the use of technology in recruitment (Langer, König, \& Fitilli, 2019). The literature on

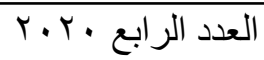$$
\text { المجلد الحادي عشر }
$$ 
Gamification and Essential Determinates of Motivational Level...

Dr/ Niveen Ezzat Aly

the effect of gamification on motivation is still limited on multiple levels. There is a gap between theory and practice in the study of gamification (Alsawaier, R. S. (2018). In addition, some authors examining applicants' reactions to selection procedures have advocated the development of empirical research to validate gamified recruitment (McCarthy et al., 2017). A recent systematic literature review has found that only $3 \%$ of the studies targeted newcomers as the audience for gamification, neither had they specifically dealt the users who are not intrinsically motivated for the serious games (Obaid, I., Farooq, M. S., \& Abid, A. 2020).

According to IT literature, one common reason-among othersfor making games fail (the users quit the game) is; motivation (Night Blade,2018). Candidate experience matters more than ever because of the use of digital technologies that facilitate sharing and communication. Negative candidate experiences can harm employers' reputation and employer brand, while positive experience would increase the referrals. Most candidates with negative experiences reported that the lack of constant communication like; "not receiving a basic application confirmation email, or received an email said the communication was weak and inconsistent" was the major reason for having a poor experience. Candidate experience has great implications on attracting qualified and talented labor as a Lloyd's of London risk index listed "talent and skill shortages" as the number two



المجلد الحادي عشر 
Gamification and Essential Determinates of Motivational Level...

Dr/ Niveen Ezzat Aly

risk facing businesses today. The use of gamification could solve the problem of decline in candidates' motivation and engagement, and hence the effectiveness of recruiting (slidelegend.com/lloyds-2011-risk-index-1loyds-of-london). In response to these calls, this study uses Self-Determination Theory (SDT) which provides a useful framework for analyzing motivation to gain a better understanding of (job-seekers) applicants' motivation to gamified recruitment tools. Selfdetermination theory (SDT) focuses on competence, relatedness, and autonomy (Deci and Ryan, 2008; Seaborn and Fels, 2015). The three elements of SDT constitute human psychological needs to make choices, to compete, and collaborate with others; all of which can be afforded in the gamified environment. According to SDT, internal goals are much more powerful drivers than external ones. The Intrinsic Motivation Inventory (IMI)- (one of the components of autonomous motivation)- is a widely accepted instrument that measures many factors relevant to selfdetermination theory and can be used to determine participants' motivation after experiencing with gamified interactive systems (Deci and Ryan, 2005). "Gaming elements profoundly rooted in human beings, intrinsically motivated behaviors are those that the player considers fascinating and performs without any kind of training, simply for the pleasure of performing them" (Francisco Aparicio et al., 2013, p. 114). The research relied only on the four sub-scales of the IMI scales, which are: Interest/ Enjoyment,

$$
\text { المجلد الحادي عشر }
$$ 
Gamification and Essential Determinates of Motivational Level...

Dr/ Niveen Ezzat Aly

Perceived Competence, Pressure/ Tension, and Perceived Choice. Based on the above, this research will focus on two point; compare motivational levels of the two groups (experimental and control) with regard to the Gamification use, and investigate the differences in motivational levels with regard to the characteristics of individuals who used gamification.

\section{Literature Review}

In this section, the researcher will shed light on the main terminologies in this research.

3.1. Motivation and Work Place

Pritchard and Ashwood (2008, p. 6) defined motivation as the "process used to allocate energy to maximize the satisfaction of needs". Motivation generates a desire within an individual to dedicate their abilities to perform. It results from the interaction of both conscious and unconscious factors such as; the intensity of desire or need, incentive or reward value of the goal, and expectations of the individual and his or her peers. These factors are the reasons one has for behaving a certain way. Internal and external factors that stimulate desire and energy in people to be continually interested and committed to a task, role, or subject, or to make an effort to attain a defined goal (Ganta, V. C. (2014). The literature on motivation has presented both process and content theories, focusing on either explaining the motivation process or describing internal characteristics, respectively.

$$
\text { العدد الرابع • r. T }
$$$$
\text { المجلد الحادي عشر }
$$ 
Gamification and Essential Determinates of Motivational Level...

Dr/ Niveen Ezzat Aly

Maslow's hierarchy of needs and two-factor theory from Herzberg are two notable content theories developed to explain motivation (Mahmoud, A. B., Fuxman, L., Mohr, I., Reisel, W. D., \& Grigoriou, N. (2020).

Another theory of motivation developed by Ryan and Deci (2000) explores self-determination. Self-determination theory (SDT) provides a multidimensional conceptualization of motivation using a self-determination continuum in which an individual's autonomy shifts from minimally present in a state of motivation to the maximum state of self-determination, where intrinsic motivation is present. Unlike the other motivation theories, SDT can be employed to identify a range of motivations and their various outcomes. SDT posits that motivation can be either encouraged or discouraged. The logic of SDT is that motivation consists of three main types that occur on a selfdetermination scale of regulatory styles. These are motivation, intrinsic motivation, and extrinsic motivation. Motivation operates through a set of regulatory styles, which are motivation, external, introjected, identified, and intrinsic regulation. (Mahmoud, A. B. et al. 2020). They vary from the greatest selfdetermined and autonomous form of motivation (intrinsic) to the least self-determined and controlled form of motivation (external). Gagne et al. (2014) asserted that three essential psychological needs of competence, autonomy, and relatedness are vital for enabling the highest performance in individuals. The

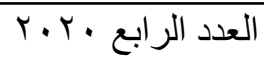$$
\text { المجلد الحادي عشر }
$$ 
Gamification and Essential Determinates of Motivational Level...

Dr/ Niveen Ezzat Aly

need for autonomy refers to the individual's desire to make their own choices and actions and to freely express their opinions (Ryan and Deci, 2017). The need for competence is defined as an individual's desire to influence the environment and to attain desired results (Ryan and Deci, 2000). The need for relatedness is described as an individual's desire to create equally helpful bonds and positive alliances with others (Ryan and Deci, 2000). Self-Determination Theory (SDT) and Gamification

Self-Determination Theory (SDT) is a famous psychological theory of human motivation, has become increasingly popular in Human-Computer Interaction research on games and play. A commonly used theoretical framework to understand the motivational potential of games is the self-determination theory (Deci \& Ryan, 2000; Deci \& Ryan, 1985; Ryan et al., 2006). SDT as macro motivation theory (Adams, Little, \& Ryan, 2017; Deci \& Ryan, 2008), is focused on the premise that the willingness and motivation of individuals, including social and cultural influences, may be affected by their environment. According to SDT, individuals tend to grow by their congenital psychological needs: autonomy, competence, and relatedness. Competence refers to the degree of individual control over the challenges faced in a particular situation. Autonomy refers to the freedom of the individual to choose the challenges faced in a specific vein, and relatedness refers to the feelings of the individual and the practice of acknowledging and accepting from

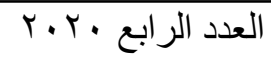$$
\text { المجلد الحادي عشر }
$$ 
Gamification and Essential Determinates of Motivational Level...

Dr/ Niveen Ezzat Aly

others (Deci \& Ryan, 2000). Studies and research have proven that all of the antecedent factors related to motivation are satisfied through playing games (Ryan et al., 2006), which all belong to the intrinsic motivation of the individual's behavior (Rigby \& Ryan, 2011). Gamification provides the component of fun that helps in transforming the users' attitudes toward a certain behavior. Fun can allow for better behavior by creating relaxation and motivation (Prensky (2001). Relaxation enables a user to take things in more easily, and motivation enables them to put forth effort without resentment. This feeling of fun is created in the players through their feeling of achievement, a sense of exploration, the reward of completing a level, or simply winning a game (Zichermann, 2010). If this element of play is incorporated into the learning experience, an intrinsic interest in the task can follow (Lieberman, 2006). The fun part in a gamified environment is the product of solving problems and overcoming challenges as they engage critical thinking skills. "Desirable difficulties," as Yue et al. (2013) called them (p. 266), are important qualities, according to Lieberman (2006). For individuals experiencing growth - to be motivated- there is a need for their belief that they can organize their actions and control the consequences, as well as their believes that they can perform the required tasks in addition to their sense of engaging in and belonging to the society. Intrinsic motivation is triggered by human needs for mastery, curiosity, and overcoming

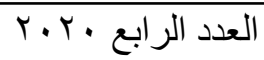

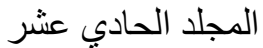


Gamification and Essential Determinates of Motivational Level...

Dr/ Niveen Ezzat Aly

challenges. These three intrinsic psychological needs are motivational resources that can be developed by modifying the environment. Thus, motivational behavior patterns can be promoted to a significant degree by deliberately addressing the human need for competence, autonomy, and social relatedness (Sailer, M., Hense, J. U., Mayr, S. K., \& Mandl, H. (2017). To maximize the feeling of autonomy, he/ she must have access to the largest possible number of alternatives that will choose. Also, directing the individual to rely on indirect methods is undoubtedly much better than a direct one to reinforce this feeling. When the individual realizes that he/ she can perform the tasks correctly, this will necessarily increase the intrinsic motivation (Deci \& Ryan, 1985; Sari, Ekici, Soyer, \& Eskiler, 2015). When the task to be accomplished is easy, this leads to the individual not feeling competent, a more difficulty the degree, the greater the sense of competence. But at the same time must be achieved with the existing skills available. (Park, Cha, Kwak, \& Chen, 2017), positive feedback on an individual's performance can maximize the feeling of competence and then enhance the level of motivation, and vice versa, as negative comments lead to a decrease in the competence and motivation as a result. (Weidinger, Spinath, \& Steinmayr, 2016). Another influential psychological state for growth is relatedness (Altintas, De Benedetto \& Gallouj, 2017) when individuals realize the relatedness to whom in a higher-order or/ and their peers that

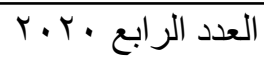$$
\text { المجلد الحادي عشر }
$$ 
Gamification and Essential Determinates of Motivational Level...

Dr/ Niveen Ezzat Aly

reinforce the intrinsic motivational level (Sparks, Dimmock, Lonsdale, \& Jackson, 2016; Cox, Duncheon, \& McDavid, 2009). When perceiving encouraging and gentle attitudes from superiors or colleagues, the individual may feel positive relationships and be highly motivated. According to SDT, the motivation consists of four sub-variables; Interest/ Enjoyment, Perceived Competence, Pressure/ Tension, Perceived Choice.

\subsection{Gamification and Employees Selection}

Recent studies confirmed that businesses in multiple industries recognize their talent management practices are no longer fulfilling their needs. Employers concentrate their efforts instead of providing a positive experience for workers to retain and maintain the talent they need. (Claus L.2019). In recent decades, technological developments have helped companies build new recruitment methods, some based on the Internet (e.g., computerized databases, online interviews, online personality tests), known as online recruitment (Brandão, Silva, \& Vieira dos Santos, 2019), and, more recently, based on social networks (e.g., LinkedIn), known as social recruitment (Doherty, 2010). Organizations are changing the way they recruit and retain skilled workers today by adopting a fresh and more fun approach to online and social recruiting; gamified recruitment (Collmus et al., 2016; McCarthy et al., 2017).

$$
\text { العدد الرابع • r. T }
$$


Gamification and Essential Determinates of Motivational Level...

Dr/ Niveen Ezzat Aly

According to new research (Georgiou. K, 2019), current innovations, including gamification, gamified tests, and serious games, have drawn more publicity recently for talent identification. Serious games are games developed for a core function other than entertainment. Gamification refers to integrating elements of the game into non-gaming activities in any vein, as for the workplace, that opening the way to gamebased evaluations and could categorize according to the level of game characteristics. Gamification was applied to selection contexts of employees to gamify assessment approaches and therefore boost candidate's reaction and likely increase work performance prediction (Armstrong, Ferrell, Collmus, \& Lenders,2016a).

The conventional techniques used in recruitment and selection have two evaluative steps: one relating to the grading of applicants for multiple-choice issues assessing traits and competences and the degree to which they possess those characteristics or competences, and the other regarding applicants' competences and actual job performance. Playing gamification as online testing may simulate scenarios where it shows individuals' thoughts and actions that would impact their level of motivation. The candidates' focus diverted from the fact that they are tested, thereby exposing their real attitudes and removing false or socially acceptable prejudices. (Armstrong, Landers, \& Collmus, 2016b). In conventional methods, Gamified

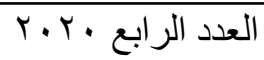$$
\text { المجلد الحادي عشر }
$$ 
Gamification and Essential Determinates of Motivational Level...

Dr/ Niveen Ezzat Aly

selection strategies can then reduce the evaluative steps, thus improving the estimate of job results. Gamification as gamified selection methods assesses the knowledge, skills, abilities, and other characteristics (KSAOs), which helped in predicting work performance similar to the traditional assessment methods. The use of gamified selection strategies can also increase engagement and boost organization credibility from the applicants' perspective, and that considered a positive competitive advantage for talented applicants (Georgiou, K. 2019). Researchers have concluded that gamification can be used to encourage a large number of candidates in the recruiting process simultaneously, improve the organizational reputation and attractiveness, and eventually have a positive effect on the applicants' behaviors. Game features can improve the selection process because the assessment processes are more difficult for users to trick, as optimal behavior may be unnoticeable to individuals playing the game and therefore increase the precision of hiring decisions. The traditional selection methods, such as personality tests, are vulnerable to counterfeiting and thus undermine their validity and reliability (Murphy \& Dzieweczynski, 2005). Gamification also can detect knowledge more precisely about the actions of candidates compared to conventional approaches such as personality inventories, since they do not have data that is selfreported (Georgiou, K.\& others 2019; Armstrong, Landers, et al., 2016b), gaming habits can test the abilities of candidates.

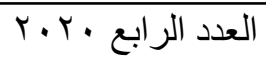$$
\text { المجلد الحادي عشر }
$$ 
Gamification and Essential Determinates of Motivational Level...

Dr/ Niveen Ezzat Aly

According to Armstrong, M.B., Ferrell, J.Z., Collmus, A.B. and Landers, R.N., (2016), they stated: "a gamified assessment is not a stand-alone game, but it is instead an existing form of assessment that has been enhanced with the addition of game elements" (p.672), that means that gamified assessments represent an advanced level of current traditional selection methods, a metamethod that incrementally enhances the ability to predict job outcomes better. (Lievens, Peeters, \& Schollaert, 2008).

\subsection{Gamification as a Response to Changes in the Labor Market}

Technological developments, globalization, cost deflation due to the global financial crisis, growing speed of business shifts, growing importance of intellectual capital, and the aging population have caused the global labor market to turn irreversibly (Dubois \& Rothwell, 2007). One measure of this is the shortage of qualified staff. A previous survey of employers predicted that the number of vacancies in 2020 would increase to 35 million worldwide due to a shortage of personnel with sufficient skills (Kupczyk, 2010). Additionally, we have all been professionally affected by COVID-19 in some respect, which certainly affects recruitment and the labor market. Working from home, virtual onboarding, truly global recruiting teams, and hiring without borders- these are only some of the issues facing the world of

$$
\text { المجلد الحادي عشر }
$$ 
Gamification and Essential Determinates of Motivational Level...

Dr/ Niveen Ezzat Aly

work today. COVID-19 has changed the way on how to navigate this market effectively to find and hire talented people.

Therefore, finding such a form of selection that would be able to verify specific competences in a short time and with success is important. Technological growth and globalization are pushing businesses to look for new ways to deal with that situation. Candidates for the job were also subject to the present-day trend of alteration. Generation Z (born after 1990) and Generation Y (born after 1980, the so-called Millennials) are tech-savvy and grew up in the information revolution therefore, view future jobs with a mindset distinct from their predecessors (McCrindle Research, 2006). Each generation has a different set of values, preferences, attitudes and communication styles. Frequent use of the IT devices, greater confidence, and commitment to their hobby means that they require the versatility of commitments from an employer to make effective use of the technologies available (Ng, Schweitzer, \& Lyons 2010). Recruiting via Skype or applying for vacancies in the business on the other side of the globe is not a challenging issue for Ys and Zs, but daily life. Though it is necessary to take this factor into account when looking for innovative ways of employee selection.

Gamification seeks and identifies individuals with different competences as a tool of selection. You may also define certain skills as talents in the case of their use (Ingram, 2011). It's not

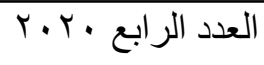$$
\text { المجلد الحادي عشر }
$$ 
Gamification and Essential Determinates of Motivational Level...

Dr/ Niveen Ezzat Aly

enough to have many features needed to win the game you have to be the best, whether in terms of time (i.e., having the ability to think quickly), creativity (if the person with the best idea for a given scenario wins) or intelligence (if the game is about problemsolving). The winner in all of these situations is at a significantly different level of qualifications from other players. They allowed him or her to get the best outcomes in the game and, therefore, often get the job. Another characteristic of gamification is the neutrality of all the candidates, games are usually posted on special websites or social networks, so they can be played by anyone interested. Due to this variety, a potential organization that uses video games as a method of recruitment will attract genuinely outstanding workers who would not be involved in the conventional recruitment process or may feel that their skills are not appropriate for the job (Zichermann \& Linder, 2003). Therefore, gamification has much in common with headhunting looking for a person with an exceptional talent who seems to match the company profile and a specific role perfectly, and then sending the offer that would be of interest to that person.

Gamification helps the applicant applying for the position to become aware of what competencies are expected of them for a position after passing the application via gamification, what duties are connected with it, and what the company's procedures are. Even if they don't get a particular position, they will be aware of their strengths and weaknesses which will help them in

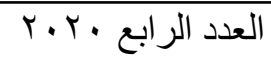$$
\text { المجلد الحادي عشر }
$$ 
Gamification and Essential Determinates of Motivational Level...

Dr/ Niveen Ezzat Aly

the future. The business, on the other hand, is assured that a given candidate is aware of the responsibilities associated with a particular role, and that the candidate will be prepared if he or she performs the given tasks. Thus, when taking into account the above gamification features as a method of assessment and selection, and the labor market alterations, one may find gamification as that considers all the criteria required.

\section{Pilot Study}

The researcher chooses a group of students (focused group) to express their insights on the topic that was studied. The results of the pilot study showed that they assured that their level of motivation was greater in the case of using gamification, and they also believed that their characteristics can make a difference in the motivational level from use the gamification. These characteristics are; age, gender, employment status, time spent on the recruiter's website and interest area. Based on the above, the research points are the following:

\subsection{Research Gap}

The literature on gamification and its impact on motivation and engagement in recruitment is still disintegrated. Researchers in IT is mainly focusing on the design aspects of gamification, while researchers in the psychological discipline are focusing on the theoretical relevance or theory-informed gamifies systems. There are not enough studies that take into account the different

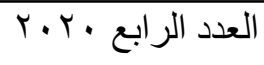$$
\text { المجلد الحادي عشر }
$$ 
Gamification and Essential Determinates of Motivational Level...

Dr/ Niveen Ezzat Aly

aspects of using gamification in the selection and recruitment steps by using IMI.

There is a divergence in the study of gamification regarding theory and practice, where the theory has not been examined in practice (experimental) and also the applied work lacks reliance on theory and reference to it, which led to the limitation of growth in this field (Seaborn and Fels, 2015, p. 27). This illustrates the need for gamification research with powerful theoretical links that span the gap between theory and practice. The research focuses on the job candidates' perspectives since there is a lack of previous studies on this perspective. Also, this aspect is extremely important for further development of forms of recruitment and selection that matching with the features of younger generations and their mastery of technologies, to build a pool of candidates that reach the most suitable candidates in a global market with the least effort, time, and money.

This research paper tries to cover the different aspects of the topic, it tries to bridge between three disciplines, IT (game elements; the game mechanics, dynamics and components), Human Psychology (intrinsic motivation theory), and HR (the effectiveness of using gamification as a recruitment technique).

\subsection{Research Problem}

- Are there significant differences in the motivational level between job seekers who used gamification-Gamification

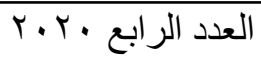$$
\text { المجلد الحادي عشر }
$$ 
Gamification and Essential Determinates of Motivational Level...

Dr/ Niveen Ezzat Aly

Group (GG) and those who did not Non-Gamification (NG)?

- Are there significant differences in the motivational level of the individuals in (GG) with regard to their characteristics?

\subsection{Research Objectives}

- This research aims to determine the extent of significant differences in motivational level between job seekers who used gamification (Gamification Group) GG and those who did not (Non-Gamification) NG.

- Also, the research aims to determine the extent of significant differences in motivational level of (GG) individuals with regard to their characteristics.

\subsection{Research Importance}

The importance of the study lies in several points. First, this research is concerned with studying the job seekers point of view as users of gamification, which is rare in the literature. Many previous researches focused on the organization or the recruiters' point of view, ignoring the users' experience and its implications. Second, the application of gamification on the human resource management context has focused on workers and employees' motivation, neglecting to study the motivation for job seekers before joining the organization despite the importance of

$$
\text { المجلد الحادي عشر }
$$ 
Gamification and Essential Determinates of Motivational Level...

Dr/ Niveen Ezzat Aly

reaching qualified and experienced job candidates thus influencing selection and appointment decisions. Third, the characteristics of the younger generations, which represent the vast majority of job seekers, require unconventional means to attract their attention and motivation, such as the need for immediate feedback, the familiarity of using any type of technology, and playing games for many hours a day. Likewise, there is no research in Arabic in this regard - according to the researcher's knowledge - due to the novelty of the topic in terms of application and therefore research and study. In addition, there is a practical importance which is

represented in the possibility of benefiting from the results of the study, as most organizations can apply the use of gamification in the selection and appointment processes efficiently and effectively.

\subsection{Hypotheses}

Based on the previous literature review, the hypotheses of the study are as following:

H1: There are significant differences in the motivational level between job seekers who used gamification (Gamification Group) GG and those who did not (Non-Gamification) NG.

H2: There are significant differences in the motivational level of the individuals in (GG) with regard to their characteristics.

$$
\text { العدد الرابع • r. T }
$$


Gamification and Essential Determinates of Motivational Level...

Dr/ Niveen Ezzat Aly

The sub hypotheses are:

H2.1: There are significant differences in the motivational level of the individuals in (GG) with regard to their age.

H2.2: There are significant differences in the motivational level of the individuals in (GG) with regard to their gender.

H2.3: There are significant differences in the motivational level of the individuals in (GG) with regard to their state of employment.

H2.4: There are significant differences in the motivational level of the individuals in (GG) with regard to the time spent on Hire Hunt website.

H2.5: There are significant differences in the motivational level of the individuals in (GG) with regard to their interest area.

\section{Research Method}

\subsection{Research Population and Sampling}

The research population is represented by all job seekers and students of the Faculty of Commerce, Cairo University (Georgia, and English Section) at the undergraduate and postgraduate levels (MBA) in the second semester of the academic year 20182019. Since the size of the population is about 3000 students, the appropriate sample size is 341 individuals according to (Hashim, Y. A. (2010). However, due to the researchers' desire to divide

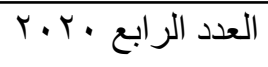$$
\text { المجلد الحادي عشر }
$$ 
Gamification and Essential Determinates of Motivational Level...

Dr/ Niveen Ezzat Aly

the study sample into two groups: an experimental group that deals with the recruiter's website (Hire Hunt website), and a test group that does not deal with the recruiter's website, and in order to apply the necessary statistical methods, the sample size was 400 individuals, directing 200 questionnaires for the test group and 200 for the experimental group. It was restricted to faculty students so that the experiment could be completed in the faculty's computer labs. The percentage of responses reached $75 \%$. The sample was convenience because of the difficulty of randomly selecting the sample items.

\subsection{Research Variables and Measures}

The study examined a number of variables as follows: Motivation Level that represents the dependent variable and includes the following four dimensions: Interest/ Enjoyment, Perceived Competence, Pressure/ Tension, Perceived Choice. It was measured using an IMI scale (McAuley, E., Duncan, T., \& Tammen, V. V. (1989), Choi, J., Mogami, T., \& Medalia, A. (2010), through 22 questions, 7 questions for the first dimension, 5 questions for the second dimension, 5 questions for the third dimension, and 5 questions for the fourth dimension. The Characteristics of the experimental group represents the independent variable and includes the five items: Age, Gender, State of Employment, Time Spent on the recruiter's website, and Interest Area. It was measured through 5 questions, one for each dimension.




Gamification and Essential Determinates of Motivational Level...

Dr/ Niveen Ezzat Aly

\subsection{Data Gathering}

The primary data collected through a structural survey list used Google Form to design and send it to the sample students. The list is included two parts, the first part deals with sentences that measure the dependent variable (level of motivation) through the choice of one of the degrees specified on the seven-point Likert scale, while (1) is strongly disagree and (7) is strongly agree. The second part of the list deals with the characteristics of the experimental group. The questions for Age, Gender, and the State of Employment were closed questions while the two others were open questions. The participants in the experimental group answered the questionnaire immediately after the completion of the gamification on the recruiter's website.

\section{Statistical Analysis}

The following statistical methods were used:

- Cronbach's Alpha to test the reliability of questionnaire used.

- Confirmatory factor analysis to test Validity

- Mean, Standard deviation (STD).

- T-test for comparing two means

- Analysis of variance (ANOVA) for comparing more than two means. 


\section{First: Means, Reliabilities and Validity}

Table (1) Validity and reliabilities of the scales and sub scales

\begin{tabular}{|c|c|c|c|c|c|c|c|}
\hline Index & Chi-square & GFI & IFI & TLI & CFI & RMR & RMSEA \\
\hline Gamification & 360 & 0.836 & 0.901 & 0.873 & 0.899 & 0.204 & 0.086 \\
\hline \multirow{3}{*}{ Non-Gamification } & 369 & 0.902 & 0.911 & 0.889 & 0.904 & 0.108 & 0.07 \\
\hline & & & & \multicolumn{2}{|c|}{ Gamification } & \multicolumn{2}{|c|}{ Non-Gamification } \\
\hline & \multicolumn{3}{|c|}{ Statements } & Estimate & Cronbach's alpha & Estimate & Cronbach's alpha \\
\hline \multirow{7}{*}{ Interest/enjoyment } & \multicolumn{3}{|c|}{$\begin{array}{l}\text { While I was working on the } \\
\text { task, I was thinking about how } \\
\text { much I enjoyed it. }\end{array}$} & 0.72 & \multirow{7}{*}{0.91} & 0.65 & \multirow{7}{*}{0.72} \\
\hline & \multicolumn{3}{|c|}{ I found the task very interesting. } & 0.775 & & 0.528 & \\
\hline & \multicolumn{3}{|c|}{ Doing the task was fun. } & 0.768 & & 0.65 & \\
\hline & \multicolumn{3}{|c|}{$\begin{array}{l}\text { I enjoyed doing the task very } \\
\text { much. }\end{array}$} & 0.838 & & 0.712 & \\
\hline & \multicolumn{3}{|c|}{$\begin{array}{l}\text { I thought the task was very } \\
\text { boring. }\end{array}$} & 0.509 & & 0.722 & \\
\hline & \multicolumn{3}{|c|}{$\begin{array}{l}\text { I thought the task was very } \\
\text { interesting. }\end{array}$} & 0.867 & & 0.805 & \\
\hline & \multicolumn{3}{|c|}{$\begin{array}{l}\text { I would describe the task as } \\
\text { very enjoyable. }\end{array}$} & 0.854 & & 0.598 & \\
\hline \multirow{5}{*}{$\begin{array}{l}\text { Perceived } \\
\text { competence }\end{array}$} & \multicolumn{3}{|c|}{ I felt tense while doing the task. } & 0.69 & \multirow{5}{*}{0.85} & 0.529 & \multirow{5}{*}{0.87} \\
\hline & \multicolumn{3}{|c|}{$\begin{array}{l}\text { I think I did pretty well at this } \\
\text { activity, compared to other } \\
\text { students. }\end{array}$} & 0.685 & & 0.618 & \\
\hline & \multicolumn{3}{|c|}{$\begin{array}{l}\text { I am satisfied with my } \\
\text { performance at this task. }\end{array}$} & 0.878 & & 0.678 & \\
\hline & \multicolumn{3}{|c|}{ I felt pretty skilled at this task. } & 0.693 & & 0.691 & \\
\hline & \multicolumn{3}{|c|}{$\begin{array}{l}\text { After working at this task for a } \\
\text { while, I felt pretty competent. }\end{array}$} & 0.78 & & 0.714 & \\
\hline \multirow{5}{*}{ Perceived choice } & \multicolumn{3}{|c|}{$\begin{array}{l}\text { I felt that it was my choice to do } \\
\text { the task. }\end{array}$} & 0.721 & \multirow{5}{*}{0.69} & 0.739 & \\
\hline & \multicolumn{3}{|c|}{$\begin{array}{l}\text { I didn't really have a choice } \\
\text { about doing the task. }\end{array}$} & 0.853 & & 0.584 & \\
\hline & \multicolumn{3}{|c|}{$\begin{array}{l}\text { I felt like I was doing what I } \\
\text { wanted to do while I was } \\
\text { working on the task. }\end{array}$} & 0.502 & & 0.5 & 0.52 \\
\hline & \multicolumn{3}{|c|}{ I felt like I had to do the task. } & 0.695 & & 0.645 & \\
\hline & \multicolumn{3}{|c|}{$\begin{array}{l}\text { I did the task because I had no } \\
\text { choice. }\end{array}$} & 0.521 & & 0.687 & \\
\hline
\end{tabular}

$$
\text { العدد الرابع • r. r }
$$


Gamification and Essential Determinates of Motivational Level...

Dr/ Niveen Ezzat Aly

\begin{tabular}{|c|c|c|c|c|c|}
\hline \multirow{5}{*}{ Pressure/tension } & $\begin{array}{l}\text { I did not feel at all nervous } \\
\text { about doing the task. }\end{array}$ & 0.869 & \multirow{5}{*}{0.76} & 0.716 & \multirow{5}{*}{0.7} \\
\hline & I felt tense while doing the task. & 0.548 & & 0.758 & \\
\hline & $\begin{array}{l}\text { I felt relaxed while doing the } \\
\text { task. }\end{array}$ & 0.529 & & he & \\
\hline & $\begin{array}{l}\text { I was anxious while doing the } \\
\text { task. }\end{array}$ & 0.605 & & 0.78 & \\
\hline & $\begin{array}{l}\text { I felt pressured while doing the } \\
\text { task. }\end{array}$ & 0.625 & & 0.725 & \\
\hline The main Dimension & The motivational level & 0.705 & 0.8 & 0.668 & 0.802 \\
\hline
\end{tabular}

It is shown in table (1) infer acceptable identical the motivational level between job seekers who used gamification (Gamification Group) GG and those who did not (Non-Gamification) NG", Confirmatory factor analysis (CFA) was used to investigate construct validity of the motivational level between job seekers who used gamification (Gamification Group) GG and those who did not (Non-Gamification) NG, Several fit indices were selected in order to test the validity, as shown from the data chisquare $=360,369$ for both groups, and it is good fit, and (GF, IFI, TLI, CFI) ranged from 0.836 to 0.911 and $\mathrm{RMR}=0.204$, 0.108 , also for RMSEA $=0.08,0.07$ and all of these indices are acceptable measurements. Also, all the estimates for Standardized Regression Weights for both groups are greater than 0.5 so, it infers the good validity for the motivational level between job seekers who used gamification (Gamification Group) GG and those who did not (Non-Gamification) NG". As shown from table (1), the scale of Gamification has high reliability as the Cronbach alpha coefficient $=0.8$ also the scale of

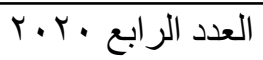$$
\text { المجلد الحادي عشر }
$$ 
Gamification and Essential Determinates of Motivational Level...

Dr/ Niveen Ezzat Aly

non-Gamification has high reliability as the Cronbach alpha coefficient $=0.82$ and the sub scales for both main scales have high reliability as the Cronbach alpha coefficient ranged from 0.7 to 0.91 , then it infers good stability for both groups.

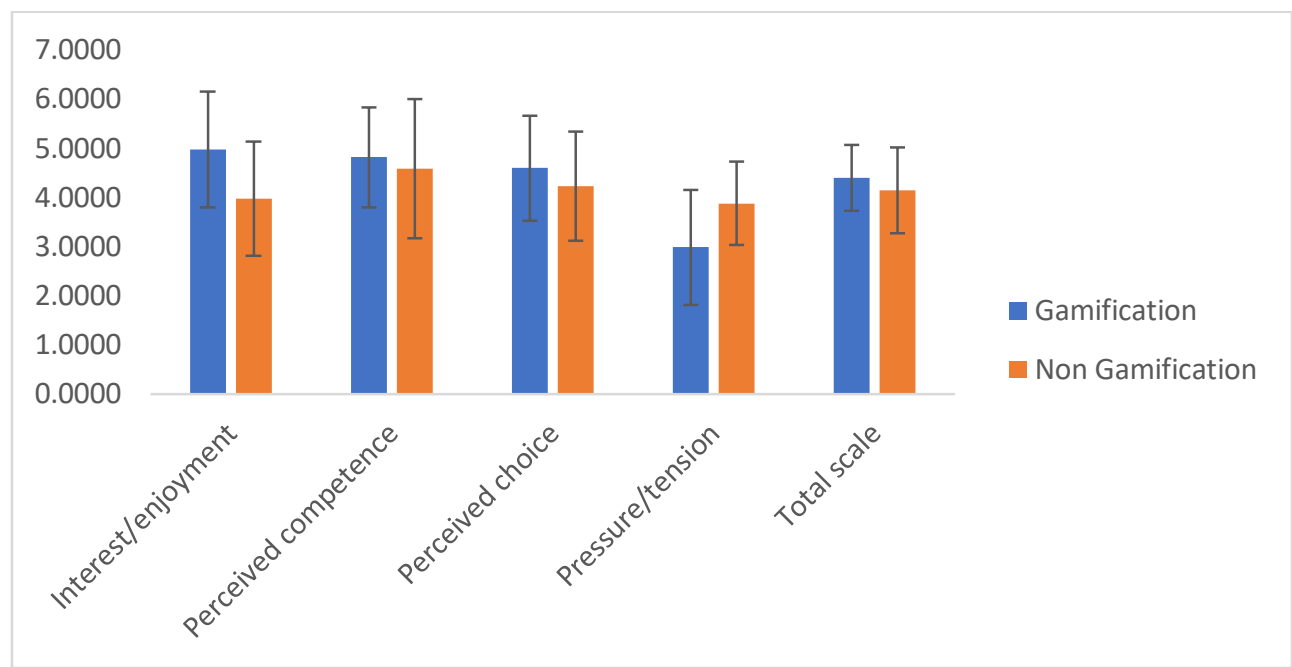

Figure (1) Means and Standard deviations for the scales

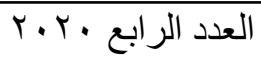


Gamification and Essential Determinates of Motivational Level...

Dr/ Niveen Ezzat Aly

\section{Second: The descriptive statistics of demographic variables}

Table (2) The descriptive statistics of demographic variables for

Gamification sample

\begin{tabular}{|c|c|c|}
\hline Personnel characteristics & No & $\%$ \\
\hline \multicolumn{3}{|c|}{ Gender } \\
\hline Male & 59 & 31.4 \\
\hline Female & 129 & 68.6 \\
\hline \multicolumn{3}{|c|}{ Age } \\
\hline $17-22$ & 152 & 80.9 \\
\hline 23-28 & 22 & 11.7 \\
\hline More than 28 & 14 & 7.4 \\
\hline \multicolumn{3}{|c|}{ State of Employment } \\
\hline Employed & 38 & 20.2 \\
\hline Un employed & 150 & 79.8 \\
\hline \multicolumn{3}{|c|}{ Topic/Interest } \\
\hline Computer science & 7 & 3.7 \\
\hline Art & 17 & 9 \\
\hline Management & 164 & 87.2 \\
\hline \multicolumn{3}{|c|}{ Time Spent on the Website/ minutes } \\
\hline less than 60 minutes & 134 & 71.3 \\
\hline $60-120$ minutes & 43 & 22.9 \\
\hline more than 120 minutes & 11 & 5.9 \\
\hline
\end{tabular}

As shown in table (2) there are 129 (68.6\%) females in the sample, and $59(31.4 \%)$ are males. Most of the sample 152 $(80.9 \%)$ are (17-22) years old, $22(11.7 \%)$ are (23-28) years old. $150(79.8 \%)$ are unemployed and $38(20.2 \%)$ are employed, the management is the most topic for the sample with $87.2 \%$, then Art with 9\%, and Computer science with 3.7\%. and most of the

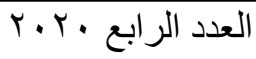


Gamification and Essential Determinates of Motivational Level...

Dr/ Niveen Ezzat Aly

sample spent less than 60 minutes on the website $(71.3 \%)$ and (23\%) spent 60-120 minutes.

The following figure show these results:
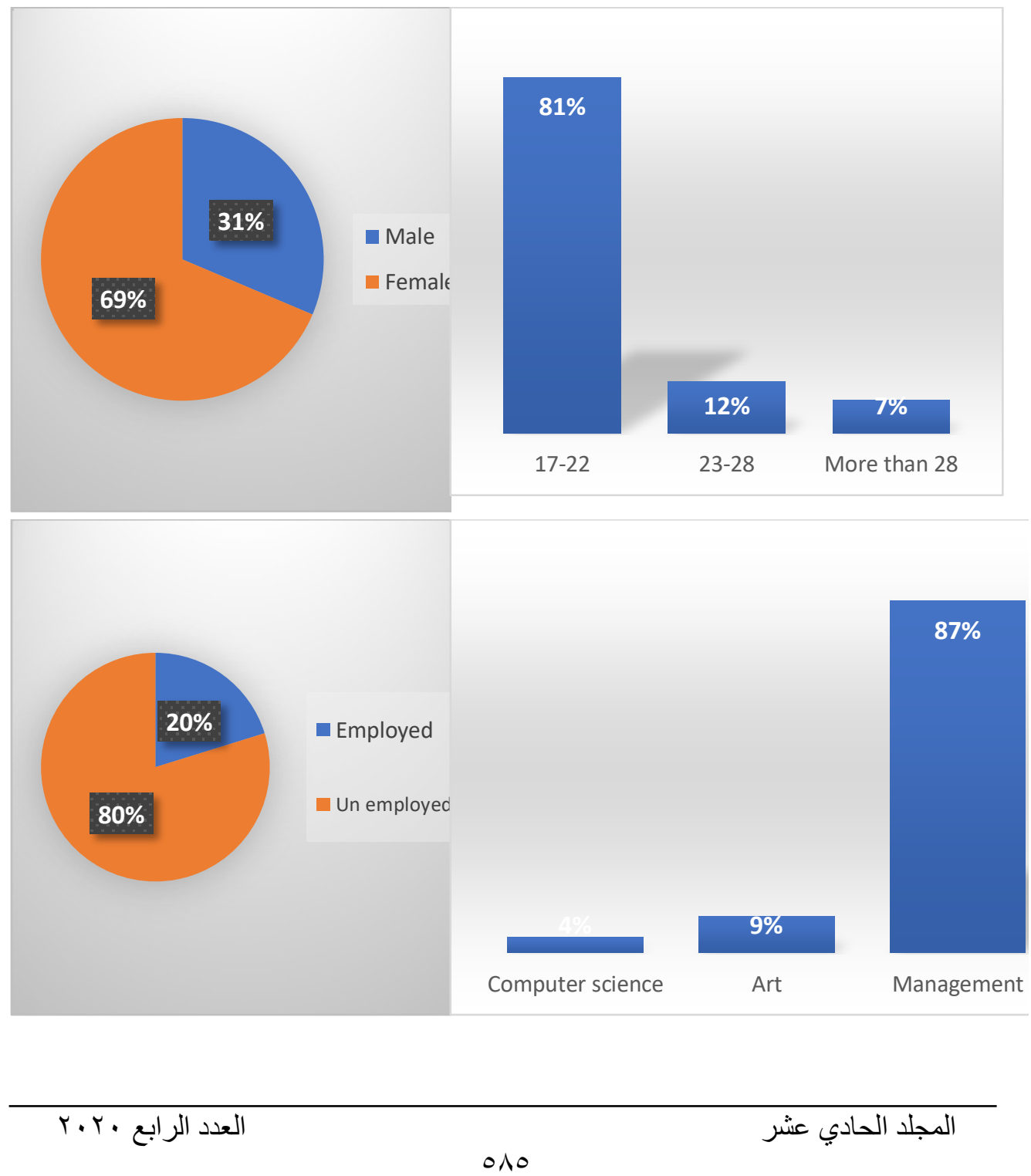
Gamification and Essential Determinates of Motivational Level...

Dr/ Niveen Ezzat Aly

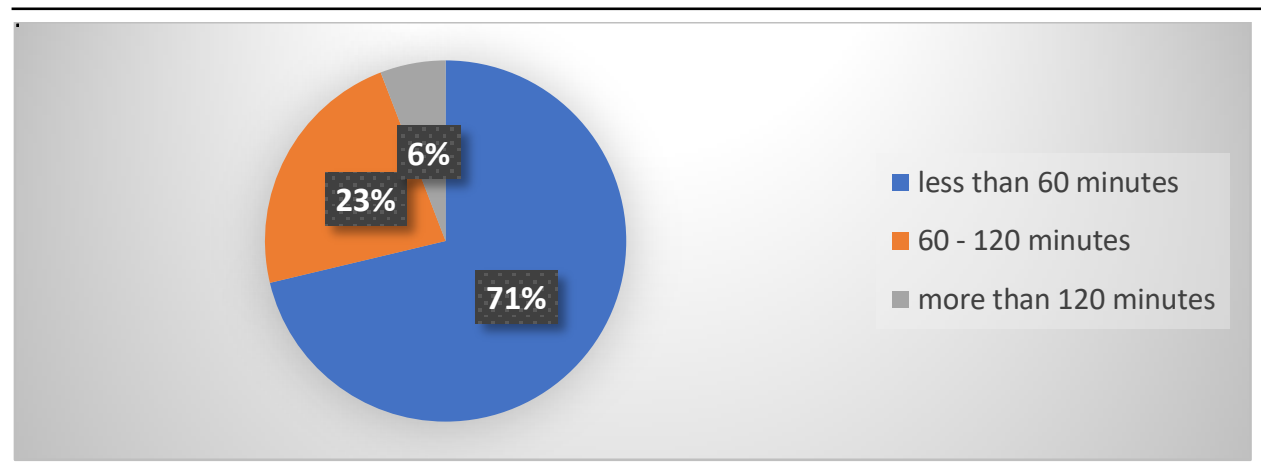

Figure (2) The descriptive statistics of demographic variables for Gamification sample

Table (3) The descriptive statistics of demographic variables for NonGamification sample

\begin{tabular}{|c|c|c|}
\hline $\begin{array}{c}\text { Personnel } \\
\text { characteristics }\end{array}$ & No & $\%$ \\
\hline \multicolumn{3}{|c|}{ Gender } \\
\hline Male & 64 & 57.1 \\
\hline Female & 48 & 42.9 \\
\hline \multicolumn{3}{|c|}{ Age } \\
\hline 17-22 & 4 & 3.6 \\
\hline 23-28 & 27 & 24.1 \\
\hline More than 28 & 81 & 72.3 \\
\hline \multicolumn{3}{|c|}{ State of Employment } \\
\hline Employed & 104 & 92.9 \\
\hline Un employed & 8 & 7.1 \\
\hline \multicolumn{3}{|c|}{ How did you send your CV to the recruiter? } \\
\hline Email & 70 & 62.5 \\
\hline in-person & 23 & 20.5 \\
\hline post office & 2 & 1.8 \\
\hline recruiter website & 9 & 8.0 \\
\hline referral & 8 & 7.1 \\
\hline 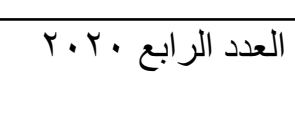 & & \\
\hline
\end{tabular}


Gamification and Essential Determinates of Motivational Level...

Dr/ Niveen Ezzat Aly

\begin{tabular}{|cc|}
\hline \multicolumn{2}{|c|}{ If employed, State the years of experience/ months } \\
\hline Mean & 134.97 \\
\hline Std. Deviation & 99.93 \\
\hline
\end{tabular}

The previous table concluded some important descriptive statistics as following:

There are 64 (57\%) females in the sample, and 48 (42.9\%) are males. Most of the sample $81(72.3 \%)$ are (more than 28 years old, 27 (24\%) are (23-28) years old. 104 (93\%) are employed, the Email is the most tool to send CV with $62.5 \%$, then in person way with $20.5 \%$, and the mean of experience by months $=135$ months with standard deviation $=100$.



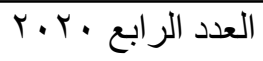


Gamification and Essential Determinates of Motivational Level...

Dr/ Niveen Ezzat Aly

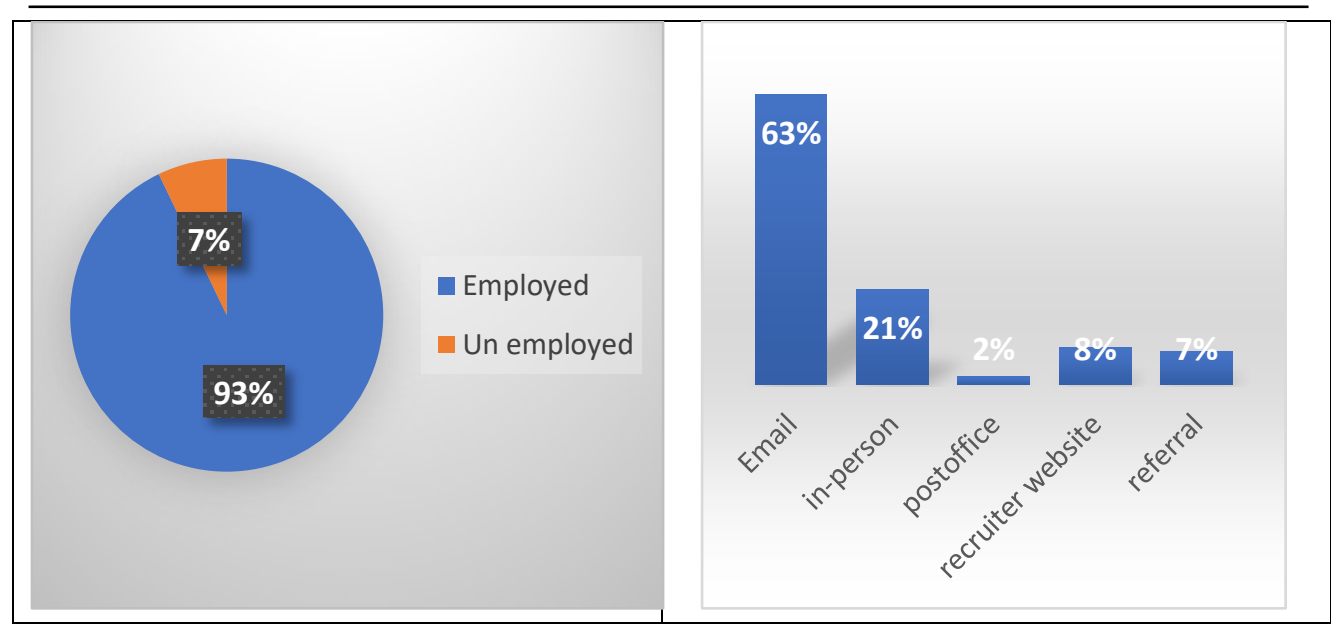

Figure (3) The descriptive statistics of demographic variables for NonGamification sample

\section{Third: The Hypotheses tests}

1- The first hypothesis "H1: There are significant differences in the motivational level between job seekers who used gamification (Gamification Group) GG and those who did not (Non-Gamification) NG"

Table (4) compare means of the motivational level between job seekers who used gamification (Gamification Group) and (Non-Gamification)

\begin{tabular}{|c|c|c|c|c|}
\hline \multirow{2}{*}{ The scale } & Gamification & Non-Gamification & \multirow{2}{*}{ T-test } & P.Value \\
\cline { 2 - 3 } & Mean \pm SD & Mean \pm SD & & \\
\hline Interest/enjoyment & $4.98 \pm 1.183$ & $3.97 \pm 1.164$ & 7.173 & 0.000 \\
\hline Perceived competence & $4.81 \pm 1.022$ & $4.59 \pm 1.41$ & 1.483 & 0.140 \\
\hline Perceived choice & $4.59 \pm 1.074$ & $4.22 \pm 1.109$ & 2.867 & 0.004 \\
\hline Pressure/tension & $2.98 \pm 1.170$ & $3.88 \pm 0.851$ & -7.626 & 0.000 \\
\hline The motivational level & $4.40 \pm 0.66$ & $4.15 \pm 0.874$ & 2.631 & 0.009 \\
\hline
\end{tabular}

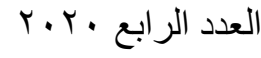

المجلد الحادي عشر 
Gamification and Essential Determinates of Motivational Level...

Dr/ Niveen Ezzat Aly

As shown in the previous table, we conclude two independent sample t-test to compare the significant differences in the motivational level between job seekers who used gamification (Gamification Group) GG and those who did not (NonGamification) NG", so at t- test value (2.63) we accept the hypothesis, as P.value $=(0.009)$ is less than 0.05 , so There is a significant difference in the motivational level between job seekers who used gamification (Gamification Group) GG and those who did not (Non-Gamification) NG", and it is favor to job seekers who used gamification (Gamification Group) GG with large mean $=4.40$. Also, there is significant difference in the sub scales for motivational level between job seekers who used gamification (Gamification Group) GG and those who did not (Non-Gamification) NG" except in case of the subscale "Perceived competence".

Based on the above statistical analyses, the first hypothesis is accepted.

2- The Second hypothesis "H2: There are significant differences at the level of motivation for individuals in the group (GG) with regard to their characteristics"

2-1- The sub hypothesis "H2.1: There are significant differences at the level of motivation for individuals in the group (GG) with regard to their ages"

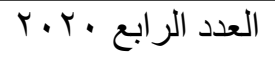

المجلد الحادي عشر 
Gamification and Essential Determinates of Motivational Level...

Dr/ Niveen Ezzat Aly

Table (5) The differences at the level of motivation for individuals in the group (GG) with regard to their ages.

\begin{tabular}{|c|c|c|c|c|c|c|}
\hline \multicolumn{7}{|c|}{ ANOVA } \\
\hline & & $\begin{array}{l}\text { Sum of } \\
\text { Squares }\end{array}$ & df & $\begin{array}{l}\text { Mean } \\
\text { Square }\end{array}$ & $\mathrm{F}$ & Sig. \\
\hline \multirow{3}{*}{ Interest/enjoyment } & $\begin{array}{c}\text { Between } \\
\text { Groups }\end{array}$ & 4.526 & 2 & 2.263 & 1.626 & 0.199 \\
\hline & $\begin{array}{l}\text { Within } \\
\text { Groups }\end{array}$ & 257.482 & 185 & 1.392 & & \\
\hline & Total & 262.008 & 187 & & & \\
\hline \multirow{3}{*}{$\begin{array}{l}\text { Perceived } \\
\text { competence }\end{array}$} & $\begin{array}{c}\text { Between } \\
\text { Groups }\end{array}$ & 1.874 & 2 & 0.937 & 0.896 & 0.410 \\
\hline & $\begin{array}{l}\text { Within } \\
\text { Groups }\end{array}$ & 193.545 & 185 & 1.046 & & \\
\hline & Total & 195.419 & 187 & & & \\
\hline \multirow{3}{*}{ Perceived choice } & $\begin{array}{c}\text { Between } \\
\text { Groups }\end{array}$ & 7.668 & 2 & 3.834 & 3.406 & 0.035 \\
\hline & $\begin{array}{l}\text { Within } \\
\text { Groups }\end{array}$ & 208.212 & 185 & 1.125 & & \\
\hline & Total & 215.880 & 187 & & & \\
\hline \multirow{3}{*}{ Pressure/tension } & $\begin{array}{c}\text { Between } \\
\text { Groups }\end{array}$ & 0.741 & 2 & 0.371 & 0.268 & 0.765 \\
\hline & $\begin{array}{l}\text { Within } \\
\text { Groups }\end{array}$ & 255.628 & 185 & 1.382 & & \\
\hline & Total & 256.369 & 187 & & & \\
\hline \multirow{3}{*}{$\begin{array}{c}\text { The motivational } \\
\text { level }\end{array}$} & $\begin{array}{l}\text { Between } \\
\text { Groups }\end{array}$ & 1.211 & 2 & 0.605 & 1.381 & 0.254 \\
\hline & $\begin{array}{l}\text { Within } \\
\text { Groups }\end{array}$ & 81.131 & 185 & 0.439 & & \\
\hline & Total & 82.342 & 187 & & & \\
\hline
\end{tabular}



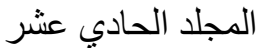


Gamification and Essential Determinates of Motivational Level...

Dr/ Niveen Ezzat Aly

As shown in the previous table, we conclude analysis of variance (ANOVA) to detect if there are significant differences at the level of motivation for individuals in the group (GG) according to their ages, so at F-test value (1.381) we reject the hypothesis, as sig value $=(0.254)$ is greater than 0.05 , so there are not significant differences at the level of motivation for individuals in the group (GG) according to their ages.

\section{2-2- The sub hypothesis "H2.2: There are significant differences at the level of motivation for individuals in the group (GG) with regard to their gender"}

Table (6) The differences at the level of motivation for individuals in the group (GG) with regard to their gender.

\begin{tabular}{|c|c|c|c|c|}
\hline \multirow{2}{*}{ The scale } & Male & Female & \multirow{2}{*}{ T-test } & \multirow{2}{*}{ P.Value } \\
\cline { 2 - 4 } & Mean \pm SD & Mean \pm SD & & \\
\hline Interest/enjoyment & $5.01 \pm 1.26$ & $4.96 \pm 1.15$ & 0.287 & 0.775 \\
\hline Perceived competence & $5.06 \pm 1.121$ & $4.70 \pm 0.95$ & 2.259 & 0.025 \\
\hline Perceived choice & $4.63 \pm 1.125$ & $4.58 \pm 1.05$ & 0.272 & 0.786 \\
\hline Pressure/tension & $2.82 \pm 1.159$ & $3.06 \pm 1.17$ & -1.297 & 0.196 \\
\hline The motivational level & $4.44 \pm 0.75$ & $4.38 \pm 0.618$ & 0.525 & 0.600 \\
\hline
\end{tabular}

As shown in the previous table, we conclude two independent sample t-test to compare the significant differences in the motivational level according the individuals gender, so at T-test value $(0.525)$ we reject the hypothesis, as sig value $=(0.600)$ is more than 0.05 , so there are not significant differences at the level of motivation for individuals in the group (GG) according

$$
\text { المجلد الحادي عشر }
$$ 
Gamification and Essential Determinates of Motivational Level...

Dr/ Niveen Ezzat Aly

to their gender, also there are not significantly differences in level of motivation according the gender in case of all subscales of level of motivation.

\section{2-3- The sub hypothesis "H2.3: There are significant differences at the level of motivation for individuals in the group (GG) with regard to the state of employment"}

Table (7) The differences at the level of motivation for individuals in the group (GG) with regard to the state of employment.

\begin{tabular}{|ccccc|c}
\hline \multirow{2}{*}{ The scale } & Employed & Unemployed & \multicolumn{1}{c}{ T-test } & \multirow{2}{*}{ P.Value } \\
& Mean \pm SD & Mean \pm SD & & \\
\hline Interest/enjoyment & $4.95 \pm 1.14$ & $4.98 \pm 1.196$ & -0.147 & 0.883 \\
\hline Perceived competence & $4.86 \pm 0.96$ & $4.80 \pm 1.039$ & 0.339 & 0.735 \\
\hline Perceived choice & $4.22 \pm 1.04$ & $4.69 \pm 1.06$ & -2.460 & 0.015 \\
\hline Pressure/tension & $3.14 \pm 1.18$ & $2.948 \pm 1.166$ & 0.912 & 0.363 \\
\hline The motivational level & $4.35 \pm 0.62$ & $4.415 \pm 0.67$ & -0.491 & 0.624 \\
\hline
\end{tabular}

As shown in the previous table, we conclude two independent sample t-test to compare the significant differences in the motivational level according the state of employment, so at T-test value $(-0.491)$ we reject the hypothesis, as sig value $=(0.624)$ is more than 0.05 , then there are not significant differences at the level of motivation for individuals in the group (GG) according to the state of employment", except the subscale (Perceived choice $)$ as P.value $=(0.015)$ so there is a significantly difference in Perceived choice according the state of employment in favor of Unemployed with large mean $=(4.69)$.

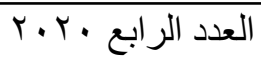$$
\text { المجلد الحادي عشر }
$$ 
Gamification and Essential Determinates of Motivational Level...

Dr/ Niveen Ezzat Aly

2-4- The sub hypothesis " $\mathbf{H 2 . 4 :}$ There are significant differences at the level of motivation for individuals in the group (GG) with regard to the time spent on the Hire Hunt website"

Table (8) The differences at the level of motivation for individuals in the group (GG) with regard to the time spent on the Hire Hunt website.

\begin{tabular}{|c|c|c|c|c|c|c|}
\hline \multicolumn{7}{|c|}{ ANOVA } \\
\hline & & $\begin{array}{l}\text { Sum of } \\
\text { Squares }\end{array}$ & df & $\begin{array}{l}\text { Mean } \\
\text { Square }\end{array}$ & $\mathrm{F}$ & Sig. \\
\hline \multirow{3}{*}{ Interest/enjoyment } & $\begin{array}{l}\text { Between } \\
\text { Groups }\end{array}$ & 1.95 & 2 & 0.973 & 0.692 & 0.502 \\
\hline & Within Groups & 260.06 & 185 & 1.406 & & \\
\hline & Total & 262.01 & 187 & & & \\
\hline \multirow{3}{*}{$\begin{array}{l}\text { Perceived } \\
\text { competence }\end{array}$} & $\begin{array}{l}\text { Between } \\
\text { Groups }\end{array}$ & 1.15 & 2 & 0.577 & 0.549 & 0.578 \\
\hline & Within Groups & 194.26 & 185 & 1.050 & & \\
\hline & Total & 195.42 & 187 & & & \\
\hline \multirow{3}{*}{ Perceived choice } & $\begin{array}{l}\text { Between } \\
\text { Groups }\end{array}$ & 2.72 & 2 & 1.361 & 1.182 & 0.309 \\
\hline & Within Groups & 213.16 & 185 & 1.152 & & \\
\hline & Total & 215.88 & 187 & & & \\
\hline \multirow{3}{*}{ Pressure/tension } & $\begin{array}{l}\text { Between } \\
\text { Groups }\end{array}$ & 1.13 & 2 & 0.564 & 0.409 & 0.665 \\
\hline & Within Groups & 255.24 & 185 & 1.380 & & \\
\hline & Total & 256.37 & 187 & & & \\
\hline \multirow{3}{*}{$\begin{array}{c}\text { The motivational } \\
\text { level }\end{array}$} & $\begin{array}{l}\text { Between } \\
\text { Groups }\end{array}$ & 0.31 & 2 & 0.157 & 0.354 & 0.702 \\
\hline & Within Groups & 82.03 & 185 & 0.443 & & \\
\hline & Total & 82.34 & 187 & & & \\
\hline
\end{tabular}

As shown in the previous table, we conclude analysis of variance (ANOVA) to detect if there are significant differences at the level

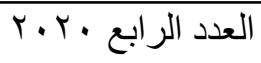$$
\text { المجلد الحادي عشر }
$$ 
Gamification and Essential Determinates of Motivational Level...

Dr/ Niveen Ezzat Aly

of motivation for individuals in the group (GG) according to the time spent on the Hire Hunt website, so at F-test value (0.354) we reject the hypothesis as sig value $=(0.702)$ is more than 0.05 , then there are not significant differences at the level of motivation for individuals in the group (GG) according to the interest, also there are not significantly differences in level of motivation according the interest area in case of all subscales of level of motivation.

\section{2-5- The sub hypothesis "H2.5: There are significant differences at the level of motivation for individuals in the group (GG) with regard to the interest area"}

Table (9) The differences at the level of motivation for individuals in the group (GG) with regard to the interest area.

\begin{tabular}{|c|c|c|c|c|c|c|}
\hline \multicolumn{7}{|c|}{ ANOVA } \\
\hline & & $\begin{array}{l}\text { Sum of } \\
\text { Squares }\end{array}$ & Df & $\begin{array}{l}\text { Mean } \\
\text { Square }\end{array}$ & $\mathrm{F}$ & Sig. \\
\hline \multirow{3}{*}{ Interest/enjoyment } & $\begin{array}{c}\text { Between } \\
\text { Groups }\end{array}$ & 0.369 & 2 & 0.185 & 0.131 & 0.878 \\
\hline & $\begin{array}{l}\text { Within } \\
\text { Groups }\end{array}$ & 261.639 & 185 & 1.414 & & \\
\hline & Total & 262.008 & 187 & & & \\
\hline \multirow{3}{*}{$\begin{array}{l}\text { Perceived } \\
\text { competence }\end{array}$} & $\begin{array}{l}\text { Between } \\
\text { Groups }\end{array}$ & 0.423 & 2 & 0.211 & 0.201 & 0.818 \\
\hline & $\begin{array}{l}\text { Within } \\
\text { Groups }\end{array}$ & 194.996 & 185 & 1.054 & & \\
\hline & Total & 195.419 & 187 & & & \\
\hline
\end{tabular}




Gamification and Essential Determinates of Motivational Level...

Dr/ Niveen Ezzat Aly

\begin{tabular}{|c|c|c|c|c|c|c|}
\hline & $\begin{array}{c}\text { Between } \\
\text { Groups }\end{array}$ & 2.670 & 2 & 1.335 & 1.158 & 0.316 \\
\hline \multirow{2}{*}{ Perceived choice } & $\begin{array}{c}\text { Within } \\
\text { Groups } \\
\text { Total }\end{array}$ & 213.210 & 185 & 1.152 & & \\
\hline & $\begin{array}{c}\text { Between } \\
\text { Groups }\end{array}$ & 7.020 & 2 & 3.510 & 2.604 & 0.077 \\
\hline & $\begin{array}{c}\text { Within } \\
\text { Groups } \\
\text { Total }\end{array}$ & 249.350 & 185 & 1.348 & & \\
\hline & $\begin{array}{c}\text { Between } \\
\text { Groups }\end{array}$ & 0.157 & 2 & 0.078 & 0.176 & 0.838 \\
\hline & $\begin{array}{c}\text { Within } \\
\text { Groups }\end{array}$ & 82.185 & 185 & 0.444 & & \\
\hline Total & 82.342 & 187 & & & \\
\hline
\end{tabular}

As shown in the previous table, we conclude analysis of variance (ANOVA) to detect if there are significant differences at the level of motivation for individuals in the group (GG) according to the interest area, so at F-test value (0.176) we reject the hypothesis as sig value $=(0.838)$ is more than 0.05 , then there are not significant differences at the level of motivation for individuals in the group (GG) according to the interest, also there are not significantly differences in level of motivation according the interest area in case of all subscales of level of motivation.

Based on the above statistical analyses, the second hypothesis is rejected. 
Gamification and Essential Determinates of Motivational Level...

Dr/ Niveen Ezzat Aly

\section{Results and Discussion}

The results of the study demonstrated that there are significant differences in the level of motivation between individuals who practiced gamification and those who did not. That is in line with the results of most previous studies in this vein. The study also confirmed the reliability and validity of the IMI scale which was confirmed in the literature review.

This paper has examined the effects of age, gender, time spent on the recruiter's website, state of employment, and the interest area on the motivational level of job-seekers who used gamification as a recruitment tool. The results of many previous studies confirmed the existence of demographic differences regarding the perception of the benefit from the use of gamification (Koivisto, J., \& Hamari, J. (2014), the results of this research showed that there was no effect of demographic differences regarding the level of motivation. That may be due to many reasons; First, the environmental differences in which the experiment was conducted, could be one reason among others. The study took place in the computer labs of the faculty while other studies were carried out using their own devices at the time and place appropriate for the users (at his/her convenience). Second, the majority of the gamification group members were in the age (17-22), represented by $80.9 \%$. Consequently, they have similarities in cultural aspects, technology knowledge, and familiarity with

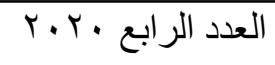




Gamification and Essential Determinates of Motivational Level...

Dr/ Niveen Ezzat Aly

playing video games. This finding holds similarities with considerations of the digital divide (Ijsselsteijn et al., 2007) between younger and older generations regarding the use of digital technologies. Third, the female percentage was $68.6 \%$ while the percentage was $31.4 \%$ for males, and this confirms the opposite of previous studies, which stated that males are the most in playing video games and consequently gamification. This finding was inconsistent with prior research showing that men value is more motivated by the use of technology (Venkatesh \& Morris, 2000). Fourth, the percentage of unemployed was $79.3 \%$, there are similarities in their behavior and their motivations regarding the search for vacancies. Also, bearing in mind that most of them are in the 17-22 age group which are tech-savvy and grew up in the information revolution. Fifth, the percentage of Management (Interest Area) was $87.2 \%$ that is the majority of the GG, which would lead to a similarity between individuals regarding the level of motivation. Finally, the time spent on the recruiter's website did not significantly affect the level of motivation, which may be due to the lack of practice gamification in the field of selection and recruitment in Egypt. There is only one recruiter company (Hire Hunt) in Egypt using Gamification as a tool for recruitment. The lack of past experiences in this regard may lead to the individual taking a

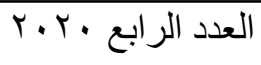$$
\text { المجلد الحادي عشر }
$$ 
Gamification and Essential Determinates of Motivational Level...

Dr/ Niveen Ezzat Aly

long time until he/ she has sufficient knowledge to practice and be familiar with the Gamification processes.

Nowadays, digital gaming is a popular activity with broad demographics. The gender divide has been diminishing, the age span has been widening, and the average age is higher than stereotypically assumed (Koivisto, J., \& Hamari, J. (2014). The concept of like-minded people also supports the research findings regarding the demographic differences (Hamari \& Koivisto, 2013).

\section{Research Implications/ Limitations and Future Researches}

The practical implication (from the industry perspective) is to design gamified recruitment would lead to an increase in the motivational level of job-seeker, that will help the organization to attract talented candidates and make the correct recruitment decisions. Furthermore, gamification service developers can benefit from the research findings by integrating environmental aspects when developing new gamification.

Theoretical implications are as follows: First, this study is characterized by novelty and genuine since it is the first experimental study of gamification taking place in Egypt. The study has also highlighted the importance of measuring motivational levels from the point of view of job seekers. Second, the research findings confirmed that




Gamification and Essential Determinates of Motivational Level...

Dr/ Niveen Ezzat Aly

demographic differences have no effects on the level of motivation, that because of the features' similarity of younger generations who are the majority of job-seekers in Egypt. Also, the results of the study are consistent with the changes that have occurred in the Egyptian labor market, so studying the effects of gamification on motivation has to take into account the environmental factors.

Some limitations should be acknowledged concerning the results of the study.

Reliance was on the student's database only, but using multiple databases would enrich the study. It was also relying on part of the IMI scale to measure the intrinsic motives only, but study both the internal and external motives will give more comprehensive results.

There are several future research points for example:

- Investigate the impact of the environmental variables on the level of motivation for gamification users.

- Investigate the differences of gamification context on the users' motivational level (e.g., Customer Services, Training and Development, Public Relation, and Crowdsourcing).

- Another future research is a longitudinal study that captures the long-term effects of the relationship between gamification and job-seekers' motivation that will become employees in the organizations.

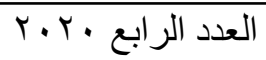

المجلد الحادي عشر 
Gamification and Essential Determinates of Motivational Level...

Dr/ Niveen Ezzat Aly

- Also, combine quantitative and qualitative research design to fully understand the long-term effects of the gamification implementation.

- Finally, investigate the impact of Gamification on Motivation through other theories (e.g., Technology Acceptance Model, Motivator-Hygiene Theory, Extrinsic and Intrinsic Motivation Theories, and Goal-Setting Theory). 
Gamification and Essential Determinates of Motivational Level...

Dr/ Niveen Ezzat Aly

\section{References}

1) Aboul-Ela, G.M.B.E., 2014. Development of a scale to measure the perceived benefits of e-recruitment from the viewpoint of the recruiter. Journal of Business \& Retail Management Research, 9(1).

2) Adefila, A., Graham, S. and Patel, A., 2020. Fast and Slow: Using Spritz for Academic Study? Technology, Knowledge and Learning, pp.1-21.

3) Albertazzi, D., Ferreira, M.G.G. and Forcellini, F.A., 2019. A Wide View on Gamification. Technology, Knowledge and Learning, 24(2), pp.191-202.

4) Allal-Chérif, O. (2014). How can information systems improve sustainable procurement policies? In Developing Business Strategies and Identifying Risk Factors in Modern Organizations (pp. 48-68). IGI Global.

5) Alsawaier, R. S. (2018). The effect of gamification on motivation and engagement. The International Journal of Information and Learning Technology.

6) Armstrong, M.B., Landers, R.N. and Collmus, A.B., 2016. Gamifying recruitment, selection, training, and performance management: Gamethinking in human resource management. In Emerging research and trends in gamification (pp. 140-165). IGI Global.

7) Bittner, J.V. and Shipper, J., 2014. Motivational effects and age differences of gamification in product advertising. Journal of consumer marketing.

8) Buil, I. Gamification and Motivation: New Tools for Talent Acquisition1. UCJC BUSINESS AND SOCIETY REVIEW | THIRD QUARTER 2019 | ISSN: 2659-3270

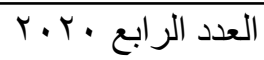


Gamification and Essential Determinates of Motivational Level...

Dr/ Niveen Ezzat Aly

9) Buil, I., Catalán, S. and Martínez, E., 2020. Understanding applicants' reactions to gamified recruitment. Journal of Business Research, 110, pp.41-50.

10) Callan, R.C., Bauer, K.N. and Landers, R.N., 2015. How to avoid the dark side of gamification: Ten business scenarios and their unintended consequences. In Gamification in education and business (pp. 553-568). Springer, Cham.

11) Choi, J., Mogami, T., \& Medalia, A. (2010). Intrinsic motivation inventory: an adapted measure for schizophrenia research. Schizophrenia bulletin, 36(5), 966-976.

12) Deci, E.L. and Ryan, R.M., 2000. The" what" and" why" of goal pursuits: Human needs and the self-determination of behavior. Psychological inquiry, 11(4), pp.227-268.

13) Deterding, S., 2015. The lens of intrinsic skill atoms: A method for gameful design. Human-Computer Interaction, 30(3-4), pp.294-335.

14) Deterding, S., Dixon, D., Khaled, R. and Nacke, L., 2011, September. From game design elements to gamefulness: defining" gamification". In Proceedings of the 15th international academic MindTrek conference: Envisioning future media environments (pp. 9-15).

15) Deterding, S., Dixon, D., Khaled, R., \& Nacke, L. (2011). From game design elements to gamefulness: defining" gamification". In Proceedings of the 15th international academic MindTrek conference: Envisioning future media environments (pp. 9-15).

16) Dreimane, S. and Daniela, L., 2020. Educational Potential of Augmented Reality Mobile Applications for Learning the Anatomy of the Human Body. Technology, Knowledge and Learning, pp.1-26. 
Gamification and Essential Determinates of Motivational Level...

Dr/ Niveen Ezzat Aly

17) Ebermann, C., Piccinini, E., Brauer, B., Busse, S. and Kolbe, L., 2016, January. The Impact of Gamification-Induced Emotions on In-car IS Adoption--The Difference between Digital Natives and Digital Immigrants. In 2016 49th Hawaii International Conference on System Sciences (HICSS) (pp. 1338-1347). IEEE.

18) Ganta, V. C. (2014). Motivation in the workplace to improve the employee performance. International Journal of Engineering Technology, Management and Applied Sciences, 2(6), 221-230.

19) Georgiou, K., Gouras, A. and Nikolaou, I., 2019. Gamification in employee selection: The development of a gamified assessment. International journal of selection and assessment, 27(2), pp.91-103.

20) Gkorezis, P., Georgiou, K., Nikolaou, I. and Kyriazati, A., 2020. Gamified or traditional situational judgement test? A moderated mediation model of recommendation intentions via organizational attractiveness. European Journal of Work and Organizational Psychology, pp.1-11.

21) Gopalia, A., 2012. Effectiveness of online recruitment and selection process: a case of Tesco. World Applied Sciences Journal, 20(8), pp.1152-1158.

22) Hamari, J. and Koivisto, J., 2015. Why do people use gamification services? International Journal of Information Management, 35(4), pp.419-431.

23) Hamari, J., 2017. Do badges increase user activity? A field experiment on the effects of gamification. Computers in human behavior, 71, pp.469-478.

24) Hamari, J., Koivisto, J. and Sarsa, H., 2014, January. Does gamification work? a literature review of empirical studies on gamification. In 2014

$$
\text { العدد الرابع • r r T }
$$$$
\text { المجلد الحادي عشر }
$$ 
Gamification and Essential Determinates of Motivational Level...

Dr/ Niveen Ezzat Aly

47th Hawaii international conference on system sciences (pp. 30253034). Ieee.

25) Hashim, Y. A. (2010). Determining sufficiency of sample size in management survey research activities. International Journal of Organisational Management \& Entrepreneurship Development, 6(1), 119-130.

26) Hassan, L., 2017. Governments should play games: Towards a framework for the gamification of civic engagement platforms. Simulation \& Gaming, 48(2), pp.249-267.

27) Herzig, P., Strahringer, S. and Ameling, M., 2012. Gamification of ERP systems-Exploring gamification effects on user acceptance constructs. In Multikonferenz $\quad$ Wirtschaftsinformatik (pp. 793-804). GITO Braunschweig.

28) Hosseini, C. and Haddara, M., 2019, October. Gamification in Enterprise Systems: A Literature Review. In Proceedings of the Future Technologies Conference (pp. 552-562). Springer, Cham.

29) https://slidelegend.com/lloyds-2011-risk-index-lloyds-oflondon 59c421c01723dd11421c4571.html

30) Huotari, K. and Hamari, J., (2012, October). Defining gamification: a service marketing perspective. In Proceeding of the 16th international academic MindTrek conference (pp. 17-22).

31) Ijsselsteijn, W., Nap, H. H., de Kort, Y., \& Poels, K. (2007, November). Digital game design for elderly users. In Proceedings of the 2007 conference on Future Play (pp. 17-22).

32) Khakpour, A. and Colomo-Palacios, R., 2020. Convergence of Gamification and Machine Learning: A Systematic Literature Review. Technology, Knowledge and Learning, pp.1-40.



المجلد الحادي عشر 
Gamification and Essential Determinates of Motivational Level...

Dr/ Niveen Ezzat Aly

33) KIROVSKA, Z., JOSIMOVSKI, S. and KISELICKI, M., (2020). MODERN TRENDS OF RECRUITMENT-INTRODUCING THE CONCEPT OF GAMIFICATION. Journal of Sustainable Development, 10(24), pp.55-65.

34) Koivisto, J. and Hamari, J., 2014. Demographic differences in perceived benefits from gamification. Computers in Human Behavior, 35, pp.179188.

35) Koivisto, J., \& Hamari, J. (2019). Gamification of physical activity: A systematic literature review of comparison studies. In 3rd International GamiFIN Conference, GamiFIN 2019. CEUR-WS.

36) Krasulak, M., 2015. Use of gamification in the process of selection of candidates for the position in the opinion of young adults in Poland. Jagiellonian Journal of Management, 1(3), pp.203-215.

37) Larson, K., 2020. Serious Games and Gamification in the Corporate Training Environment: A Literature Review. TechTrends, 64(2), pp.319328.

38) Lennefer, T., Reis, D., Lopper, E. and Hoppe, A., 2020. A step away from impaired well-being: a latent growth curve analysis of an intervention with activity trackers among employees. European Journal of Work and Organizational Psychology, pp.1-14.

39) Lepper, M.R., Corpus, J.H. and Iyengar, S.S., 2005. Intrinsic and extrinsic motivational orientations in the classroom: Age differences and academic correlates. Journal of educational psychology, 97(2), p.184.

40) Lieberman, D.A. (2006), "What can we learn from playing interactive games?", in Vorder, P. and Bryant, J. (Eds), Playing Video Games, Responses, and Consequences, Lawrence Erlbaum Associates Inc, Mahwah, NJ, pp. 379-397

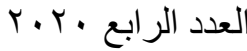

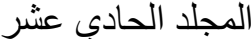


Gamification and Essential Determinates of Motivational Level...

Dr/ Niveen Ezzat Aly

41) Lister, C., West, J.H., Cannon, B., Sax, T. and Brodegard, D., 2014. Just a fad? Gamification in health and fitness apps. JMIR serious games, 2(2), p.e9.

42) Liu, D., Santhanam, R. and Webster, J., 2017. Toward Meaningful Engagement: A Framework for Design and Research of Gamified Information Systems. MIS quarterly, 41(4).

43) Lopes, S., Pereira, A., Magalhães, P., Oliveira, A. and Rosário, P., 2019. Gamification: focus on the strategies being implemented in interventions: a systematic review protocol. BMC research notes, 12(1), pp. $1-5$.

44) Mahmoud, A. B., Fuxman, L., Mohr, I., Reisel, W. D., \& Grigoriou, N. (2020). "We aren't your reincarnation!" workplace motivation across X, $\mathrm{Y}$ and $\mathrm{Z}$ generations. International Journal of Manpower.

45) Malaby, T.M., 2007. Beyond play: A new approach to games. Games and culture, 2(2), pp.95-113.

46) Malhotra, R.S. and Sharma, S., 2015. Effect of E-Recruitment on Recruitment. International Journal of Management and Commerce Innovations, pp.1047-1050.

47) McAuley, E., Duncan, T., \& Tammen, V. V. (1989). Psychometric properties of the Intrinsic Motivation Inventory in a competitive sport setting: A confirmatory factor analysis. Research quarterly for exercise and sport, 60(1), 48-58.

48) Mekler, E.D., Brühlmann, F., Tuch, A.N. and Opwis, K., 2017. Towards understanding the effects of individual gamification elements on intrinsic motivation and performance. Computers in Human Behavior, 71, pp.525-534. 
Gamification and Essential Determinates of Motivational Level...

Dr/ Niveen Ezzat Aly

49) Mitchell, R., Schuster, L. and Drennan, J., 2017. Understanding how gamification influences behaviour in social marketing. Australasian Marketing Journal (AMJ), 25(1), pp.12-19.

50) Mora, A., Riera, D., Gonzalez, C. and Arnedo-Moreno, J., 2015, September. A literature review of gamification design frameworks. In 2015 7th International Conference on Games and Virtual Worlds for Serious Applications (VS-Games) (pp. 1-8). IEEE.

51) Morris, M. G., \& Venkatesh, V. (2000). Age differences in technology adoption decisions: Implications for a changing work force. Personnel psychology, 53(2), 375-403.

52) Obaid, I., Farooq, M.S. and Abid, A., 2020. Gamification for Recruitment and Job Training: Model, Taxonomy, and Challenges. IEEE Access, 8, pp.65164-65178.

53) Pouryazdan, M., Fiandrino, C., Kantarci, B., Soyata, T., Kliazovich, D. and Bouvry, P., 2017. Intelligent gaming for mobile crowd-sensing participants to acquire trustworthy big data in the internet of things. IEEE Access, 5, pp.22209-22223.

54) Prensky, M. (2001), Digital Game-Based Learning, McGraw Hill, New York, NY.

55) Pritchard, R., \& Ashwood, E. (2008). Managing motivation: A manager's guide to diagnosing and improving motivation. Psychology press.

56) Robson, K., Plangger, K., Kietzmann, J.H., McCarthy, I. and Pitt, L., 2015. Is it all a game? Understanding the principles of gamification. Business horizons, 58(4), pp.411-420.

57) RoyChowdhury, T. and Srimannarayana, M., 2013. Applicants' perceptions on online recruitment procedures. Management and Labour Studies, 38(3), pp.185-199.



المجلد الحادي عشر 
Gamification and Essential Determinates of Motivational Level...

Dr/ Niveen Ezzat Aly

58) Ryan, R.M., Rigby, C.S. and Przybylski, A., 2006. The motivational pull of video games: A self-determination theory approach. Motivation and emotion, 30(4), pp.344-360.

59) Rynes, S.L., Bretz Jr, R.D. and Gerhart, B., 1991. The importance of recruitment in job choice: A different way of looking. Personnel psychology, 44(3), pp.487-521.

60) Sailer, M., Hense, J. U., Mayr, S. K., \& Mandl, H. (2017). How gamification motivates: An experimental study of the effects of specific game design elements on psychological need satisfaction. Computers in Human Behavior, 69, 371-380.

61) Sailer, M., Hense, J., Mandl, H. and Klevers, M., 2017. Fostering development of work competencies and motivation via gamification. In Competence-based Vocational and Professional Education (pp. 795818). Springer, Cham.

62) Santhanam, R., Liu, D. and Shen, W.C.M., 2016. Research NoteGamification of technology-mediated training: Not all competitions are the same. Information systems research, 27(2), pp.453-465.

63) Schmit, M.J. and Ryan, A.M., 1997. Applicant withdrawal: The role of test-taking attitudes and racial differences. Personnel psychology, 50(4), pp.855-876.

64) Seaborn, K., \& Fels, D. I. (2015). Gamification in theory and action: A survey. International Journal of human-computer studies, 74, 14-31.

65) Serrat, O. (2017). Social network analysis. In Knowledge solutions (pp. 39-43). Springer, Singapore.

66) Shane, M., Wisnudrajat, L., Wang, G. and Kaburuan, E.R., 2020. Implementing Gamification on a Web-Based Recruitment System using Marczewski's Gamification Framework: An Overview. International Journal, 9(3).

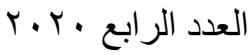

المجلد الحادي عشر 
Gamification and Essential Determinates of Motivational Level...

Dr/ Niveen Ezzat Aly

67) Shree, S. and Singh, A.S., 2019. Exploring Gamification for Recruitment through Actor Network Theory. South Asian Journal of Human Resources Management, 6(2), pp.242-257.

68) Silic, M., Marzi, G., Caputo, A. and Bal, P.M., 2020. The effects of a gamified human resource management system on job satisfaction and engagement. Human Resource Management Journal, 30(2), pp.260-277.

69) Sparks, C., Dimmock, J., Lonsdale, C. and Jackson, B., 2016. Modeling indicators and outcomes of students' perceived teacher relatedness support in high school physical education. Psychology of Sport and Exercise, 26, pp.71-82.

70) Stanescu, D.F., Ioniţă, C. and Ioniţă, A.M., 2020. Game-thinking in Personnel Recruitment and Selection: Advantages and Disadvantages. Postmodern Openings, 11(2), pp.267-276.

71) Strenitzerová, M., 2016. HR MARKETING IN TERMS OF HR MANAGERS AND EMPLOYEES-APPLICATION E-MARKETING TOOLS. Marketing Identity, 4(1/2), pp.463-473.

72) Sultana, N. and Sultana, N., 2017. Analyzing the Effectiveness of Online Recruitment: A Case Study on Recruiters of Bangladesh. Asian Business Review, 7(2), pp.10-84.

73) Taylor, G., Jungert, T., Mageau, G.A., Schattke, K., Dedic, H., Rosenfield, S. and Koestner, R., 2014. A self-determination theory approach to predicting school achievement over time: The unique role of intrinsic motivation. Contemporary Educational Psychology, 39(4), pp.342-358.

74) Țîru, L.G. and Mohorâta, M., 2020. Attitudes toward e-recruitment. An explorative study in Romania. Academicus, (21), p.73. 
Gamification and Essential Determinates of Motivational Level...

Dr/ Niveen Ezzat Aly

75) Tosca, A., Ionita, C., Stanescu, D.F. and Stanciu, A., 2019. Innovative solutions for online recruitment-gamified assessment. Postmodern Openings, 10(1), pp.151-164.

76) Woods, S.A., Ahmed, S., Nikolaou, I., Costa, A.C. and Anderson, N.R., 2020. Personnel selection in the digital age: a review of validity and applicant reactions, and future research challenges. European Journal of Work and Organizational Psychology, 29(1), pp.64-77.

77) Woźniak, J., 2015. The use of gamification at different levels of erecruitment. Management Dynamics in the Knowledge Economy, 3(2), pp.257-278.

78) Wünderlich, N.V., Gustafsson, A., Hamari, J., Parvinen, P. and Haff, A., 2020. The great game of business: Advancing knowledge on gamification in business contexts.

79) Yue, C.L., Bjork, E.L. and Bjork, R.A. (2013), "Reducing verbal redundancy in multimedia learning: an undesired desirable difficulty?", Journal of Educational Psychology, Vol. 105 No. 2, pp. 266-277, available at: https://doi.org/10.1037/a0031971

80) Zichermann, G. (2010), "Fun is the future: mastering gamification", Google Tech Talk, October 26, available at: $w w w . y o u t u b e . c o m / w a t c h ? v=601 \mathrm{gNVeaE} 4 \mathrm{~g}$ (accessed November 23, 2020). 